\title{
Hepatitis B and hepatitis $C$ viral infections in patients with chronic lymphocytic leukemia
}

\author{
Gerald Y Minuk MD1, Betty Lerner MSc${ }^{1}$, Spencer B Gibson $\mathrm{PhD}^{2}$, James B Johnston $\mathrm{MD}^{2}$, \\ Julia Uhanova MD PhD1, Anton Andonov MD PhD', Jun Wu MD PhD ${ }^{3}$
}

GY Minuk, B Lerner, S Gibson, et al. Hepatitis B and hepatitis C viral infections in patients with chronic lymphocytic leukemia. Can J Gastroenterol Hepatol 2014;28(3):131-134.

BACKGROUND: Whether chronic hepatitis B virus (HBV) or hepatitis $\mathrm{C}$ virus (HCV) infections contribute to the pathogenesis and/or course of chronic lymphocytic leukemia is unclear.

OBJECTIVE: To document the prevalences of HBV and HCV infections in chronic lymphocytic leukemia patients, and to determine whether infected patients experience more aggressive disease than those without infection.

METHODS: Patient sera were screened for antibodies to HBV core antigen and HCV (anti-HCV) using ELISA; both sera and peripheral blood lymphocytes were further tested (regardless of antibody results) for HBV-DNA and HCV-RNA using real-time polymerase chain reaction. Prognostic markers for chronic lymphocytic leukemia included Rai stage, $\operatorname{Ig} V_{H}$ mutational status, $\beta_{2}$-microglobulin levels, Zap-70 and CD38 status.

RESULTS: Fourteen of $222(6.3 \%)$ chronic lymphocytic leukemia patients and two of $72(2.8 \%)$ healthy controls tested positive for previous or ongoing HBV infection (OR 2.4 [95\% CI 0.5 to 7.7]; $\mathrm{P}=0.25)$ while four of $222(1.8 \%)$ chronic lymphocytic leukemia patients and one of $72(1.4 \%)$ controls tested positive for HCV markers (OR 1.3 [95\% CI 0.2 to 6.4]; $\mathrm{P}=0.81$ ). The levels and distribution of the various indicators of aggressive chronic lymphocytic leukemia disease were similar among HBV- and HCV-infected and uninfected patients. Survival times were also similar. Occult HBV and HCV infection (HBV-DNA or HCV-RNA positive in the absence of diagnostic serological markers) were uncommon in chronic lymphocytic leukemia patients $(0.5 \%$ and $1.8 \%$, respectively).

CONCLUSIONS: The results of the present study do not support the hypothesis that HBV or HCV infections play an important role in the pathogenesis or course of chronic lymphocytic leukemia.

Key Words: Leukemia; Occult hepatitis; Viral hepatitis

\section{Les infections virales par l'hépatite $B$ et l'hépatite $\mathrm{C}$ chez les patients atteints d'une leucémie lymphoïde chronique}

HISTORIQUE : On ne sait pas si les infections par le virus de l'hépatite $\mathrm{B}(\mathrm{VHB})$ ou de l'hépatite $\mathrm{C}(\mathrm{VHC})$ contribuent à la pathogenèse ou à l'évolution de la leucémie lymphoïde chronique.

OBJECTIF : Rendre compte de la prévalence des infections par le virus de l'hépatite $\mathrm{B}(\mathrm{VHB})$ et de l'hépatite $\mathrm{C}(\mathrm{VHC})$ chez les patients atteints d'une leucémie lymphoïde et déterminer si les patients infectés sont atteints d'une maladie plus agressive que ceux qui ne sont pas infectés.

MÉTHODOLOGIE : Les chercheurs ont recherché des anticorps contre l'antigène capsidique du VHB et contre le VHC (anti-VHC) dans le sérum des patients au moyen du test ELISA. Ils ont testé à la fois le sérum et les lymphocytes du sang périphérique (quels que soient les résultats des anticorps) pour déterminer l'ARN-VHB et l'ARN-VHC au moyen de la réaction en chaîne de la polymérase en temps réel. Les marqueurs pronostiques de leucémie lymphoïde chronique incluaient le stade de Rai, le statut de mutation de l'IgV $V_{H}$, les taux de $\beta_{2}$-microglobulines et le statut du ZAP-70 et du CD38.

RÉSULTATS : Quatorze de 222 patients atteints d'une leucémie lymphoïde chronique $(6,3 \%)$ et deux des 72 sujets témoins en santé $(2,8 \%)$ étaient positifs à une infection par le VHB antérieure ou en cours (RRR $2,4$ [95 \% IC 0,5 à 7,7]; $\mathrm{P}=0,25)$, tandis que quatre des 222 patients atteints d'une leucémie lymphoïde chronique $(1,8 \%)$ et un des 72 sujets témoins $(1,4 \%)$ étaient positifs aux marqueurs du VHC (RRR 1,3 [95 \% IC 0,2 à 6,4]; $\mathrm{P}=0,81$ ). Le taux et la distribution des divers indicateurs de leucémie lymphoïde chronique agressive étaient semblables chez les patients infectés ou non par le VHB et le VHC. La durée de survie était également similaire. L'infection occulte par le VHB et le VHC (positive à l'ARN-VHB ou à l'ARN-VHC en l'absence de marqueurs sérologiques diagnostiques) était peu courante chez les patients atteints d'une leucémie lymphoïde chronique $(0,5 \%$ et $1,8 \%$, respectivement).

CONCLUSIONS: D'après les résultats de la présente étude, les infections par le VHB ou le VHC ne jouent pas un rôle important dans la pathogenèse ou l'évolution de la leucémie lymphoïde chronique.

$\mathrm{HCV}$ in the general population; the use of serological markers alone for documenting evidence of viral exposure (infection with both viruses may exist in the absence of positive serological, diagnostic testing); and limiting viral nucleic acid (HBV-DNA and HCV-RNA) testing to patient sera or plasma without including peripheral blood mononuclear cells or lymphocytes (23). Accordingly, in the present study, we tested a large number of North American adults who had been followed in a chronic lymphocytic leukemia clinic for evidence of previous or ongoing HBV and HCV infection using both serological and nucleic acid assays of patient sera and peripheral blood mononuclear cells. The results of the viral studies were correlated with patient clinical parameters, prognostic variables and survival times.
$\mathrm{B}_{\text {have been implicated in the pathogenesis of chronic lympho- }}^{\text {oth the hepatitis B virus (HBV) and hepatitis } \mathrm{C} \text { virus (HCV) }}$ cytic leukemia (1-3). In support of this hypothesis are: epidemiological data describing associations between each virus and other hematological malignancies; the presence of viral replicative intermediates in peripheral blood mononuclear cells; and findings that each virus encodes for proteins with oncogenic potential (4-16). However, studies specifically designed to document the prevalence of HBV and/or HCV in patients with chronic lymphocytic leukemia are limited and have reported variable results $(17-22)$. This variability could, in part, reflect the small number of chronic lymphocytic leukemia subjects studied; different 'background' prevalences of HBV and
${ }^{1}$ Section of Hepatology, Department of Medicine; ${ }^{2}$ Manitoba Institute of Cell Biology, University of Manitoba, Winnipeg, Manitoba; ${ }^{3}$ Blood Safety

Surveillance Division, Public Health Agency of Canada

Correspondence: Dr Gerald Y Minuk, University of Manitoba, John Buhler Research Centre, 715 McDermot Avenue, Winnipeg, Manitoba R3E 3P4.

Telephone 204-789-3204, fax 204-789-3987, e-mail gerald.minuk@med.umanitoba.ca 
TABLE 1

Clinical and laboratory features of the study patients

\begin{tabular}{lccc}
\hline Feature & CLL $(\mathbf{n}=\mathbf{2 2 2})$ & Controls $(\mathbf{n}=\mathbf{7 2})$ & $\mathbf{P}$ \\
\hline Male sex, $\mathrm{n}(\%)$ & $137(62)$ & $25(35)$ & 0.0001 \\
Age, years & $62 \pm 12$ & $50 \pm 16$ & 0.0001 \\
Creatinine $^{*}, \mu \mathrm{mol} / \mathrm{L}$ & $85.3 \pm 20.4$ & Not tested & \\
${\text { Immunoglobulin } \mathrm{A}^{\dagger}, \mathrm{g} / \mathrm{L}}^{\text {Immunoglobulin }} \mathrm{G}^{\ddagger}, \mathrm{g} / \mathrm{L}$ & $1.4 \pm 1.1$ & Not tested & \\
Immunoglobulin $^{\S}, \mathrm{g} / \mathrm{L}$ & $8.9 \pm 6.2$ & Not tested & \\
M band, \% present & $0.7 \pm 0.9$ & Not tested & \\
\hline
\end{tabular}

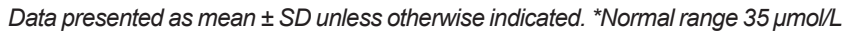
to $97 \mu \mathrm{mol} / \mathrm{L}$; ${ }^{\dagger}$ Normal range $0.7 \mathrm{~g} / \mathrm{L}$ to $3.8 \mathrm{~g} / \mathrm{L}$; ${ }^{\dagger}$ Normal range $6.9 \mathrm{~g} / \mathrm{L}$ to $16.2 \mathrm{~g} / \mathrm{L}$; $\S$ Normal range $0.6 \mathrm{~g} / \mathrm{L}$ to $2.6 \mathrm{~g} / \mathrm{L}$. CLL Chronic lymphocytic leukemia

\section{METHODS}

\section{Study patients}

After obtaining informed written consent, peripheral blood samples were collected from newly diagnosed patients attending the Chronic Lymphocytic Leukemia Clinic at CancerCare Manitoba and stored in the Manitoba chronic lymphocytic leukemia tumour bank, which is housed in the Manitoba Institute of Cell Biology, Winnipeg, Manitoba. The diagnosis of chronic lymphocytic leukemia was based on peripheral blood morphology and the presence of monoclonal B cells in the peripheral blood with typical immunophenotypes $\left(\mathrm{CD} 19^{+}, \mathrm{CD}^{+}\right.$and $\mathrm{CD}^{2} 3^{+}$) and a peripheral blood B cell count $>5 \times 10^{9} / \mathrm{L}$ (24). Prognostic markers (in addition to Rai stage) were analyzed on banked samples and included $\operatorname{Ig} V_{H}$ mutational status, plasma $\beta_{2}$-microglobulin levels, and Zap-70 and CD38 status. $\operatorname{Ig} V_{H}$ mutational status was measured using previously described methods $(25,26)$. Zap-70 and CD38 were measured using flow cytometry and considered to be positive if $\geq 20 \%$ cells stained positively. The control population consisted of volunteers who did not have a history of cancer. They were enrolled from public advertisements and/or were relatives of patients or hospital volunteers. Ethnicity was not documented for patients or controls.

\section{$\mathrm{HBV}$ and $\mathrm{HCV}$ testing}

HBV: All patient and control sera were tested for immunoglobulin $\mathrm{G}$ antibody to HBV core antigen (anti-HBc) by the CORE $1 \mathrm{Mx}$ system (Abbott Laboratories, USA). Samples that tested positive were then tested for $\mathrm{HBV}$ surface antigen $(\mathrm{HBsAg})$ and antibody to $\mathrm{HBs} \mathrm{Ag}$ (anti-HBs) using third-generation monoclonal enzyme immunoassays according to manufacturer's instructions (AUSZYME Monoclonal Diagnostic Kits, and AUSAB IMx system, Abbott Laboratories, USA).

A commercially available kit (High Pure Viral Nuclei Acid Isolation Kit, Roche Diagnostics, Canada) was used to extract DNA from sera and peripheral blood lymphocytes. These extractions (regardless of the results of anti-HBc testing) were then tested for HBV-DNA by real-time polymerase chain reaction (PCR) using the LightCycler Real-Time PCR HBV, Absolute Quantification kit according to manufacturer's instructions (TIB Molbiol, LLC, USA). The lower limit of detection was 50 viral copies $/ \mathrm{mL}$ or $10 \mathrm{IU} / \mathrm{mL}$.

HCV: Patient and control sera were tested for antibody to HCV (anti$\mathrm{HCV}$ ) using the HCV EIA version 2.0 kit (Abbott Laboratories, USA); reactive samples were retested using the Innogenetic assay (Inno-Lia HCV Ab 111 Update). Samples were considered to be antiHCV positive when both tests were positive.

RNA was extracted from sera and peripheral blood lymphocytes (regardless of anti-HCV test results) using the High Pure Viral Nucleic Acid Isolation kit (Roche Diagnostics, Canada). HCV-RNA testing was performed using the Cobas Taqman assay according to the manufacturer's instructions (limit of detection 75 viral copies $/ \mathrm{mL}$ or $15 \mathrm{IU} / \mathrm{mL}$ ).

To prevent carryover contamination during PCR, each step of the procedure was performed in a separate room with dedicated equipment and directional flow from the beginning of the procedure to the end.
TABLE 2

Chronic lymphocytic leukemia (CLL) and healthy control patients with evidence of hepatitis B virus (HBV) infection

\begin{tabular}{|c|c|c|c|c|c|}
\hline \multirow[b]{2}{*}{ CLL patient } & \multirow[b]{2}{*}{ Sex } & \multirow[b]{2}{*}{ Age, years } & \multirow[b]{2}{*}{ Anti-HBc } & \multicolumn{2}{|c|}{ HBV DNA } \\
\hline & & & & Serum & Lymphocytes \\
\hline 1 & Male & 41 & + & - & - \\
\hline 2 & Male & 47 & + & - & - \\
\hline 3 & Male & 51 & + & - & - \\
\hline 4 & Male & 54 & + & - & - \\
\hline 5 & Male & 62 & + & - & - \\
\hline 6 & Male & 74 & + & - & - \\
\hline 7 & Female & 53 & + & - & - \\
\hline 8 & Female & 55 & + & - & - \\
\hline 9 & Female & 56 & + & - & - \\
\hline 10 & Female & 80 & + & - & - \\
\hline 11 & Female & 83 & + & - & - \\
\hline 12 & Male & 58 & - & + & - \\
\hline 13 & Male & 59 & - & + & - \\
\hline 14 & Female & 62 & - & - & + \\
\hline \multicolumn{6}{|l|}{ Controls } \\
\hline 1 & Female & 51 & - & - & + \\
\hline 2 & Female & 53 & - & - & + \\
\hline
\end{tabular}

- Negative; + Positive; Anti-HBc Antibody to hepatitis B core antigen

Negative control samples containing serum or water were also included in each extraction run, and an extra negative control containing water was included during each PCR run.

\section{Statistical analysis}

For categorical variables, between-group comparisons were performed using the Mantel-Haenszel $\chi^{2}$ method. For comparison of continuous variables, the Mann-Whitney $U$ test was used. Data management and analyses were performed using Excel (Microsoft Corporation, USA) and SAS version 9.1.3 (SAS Institute Inc, USA).

Permission to perform the present study was obtained from the University of Manitoba Health Research Ethics Board (Winnipeg, Manitoba).

\section{RESULTS}

\section{Demographics}

The study patients consisted of 222 chronic lymphocytic leukemia patients and 72 healthy controls (Table 1). There were significantly more males in the chronic lymphocytic leukemia group (62\% versus $35 \% ; \mathrm{P}<0.0001)$ and chronic lymphocytic leukemia patients were older (mean $[ \pm \mathrm{SD}]$ age $62 \pm 12$ versus $50 \pm 16$ years; $\mathrm{P}<0.0001$ ) than controls.

\section{HBV testing}

The results of HBV testing are summarized in Table 2. Serum anti$\mathrm{HBc}$ testing was positive in 11 of $222(8.0 \%)$ chronic lymphocytic leukemia patients and zero of 72 controls $(\mathrm{P}=0.054)$. All 11 anti-HBcpositive chronic lymphocytic leukemia patients were negative for HBsAg while seven (64\%) were anti-HBs positive.

With respect to HBV-DNA testing of sera, two $(0.9 \%)$ chronic lymphocytic leukemia and no controls were HBV-DNA positive $(\mathrm{P}=0.42)$. Both chronic lymphocytic leukemia patients were anti-HBc negative.

HBV DNA testing of peripheral blood lymphocytes was positive in one $(0.5 \%)$ additional chronic lymphocytic leukemia and two $(2.8 \%)$ controls $(\mathrm{P}=0.09)$. These three individuals were neither anti-HBc nor HBV-DNA positive in sera. Thus, overall, 14 chronic lymphocytic leukemia patients $(6.3 \%)$ and two controls $(2.8 \%)$ tested positive for evidence of previous or ongoing HBV infection (OR 2.4 [95\% CI 0.5 to 7.7]; $\mathrm{P}=0.25$ ). 
TABLE 3

Comparisons of hepatitis B virus (HBV)-positive and HBVnegative chronic lymphocytic leukemia patients

\begin{tabular}{lccc}
\hline & \multicolumn{2}{c}{ HBV } & \\
\cline { 2 - 3 } Characteristic (normal range) & $\begin{array}{c}\text { Positive } \\
(\mathbf{n = 1 4 )}\end{array}$ & $\begin{array}{c}\text { Negative } \\
(\mathbf{n}=\mathbf{2 0 4})\end{array}$ & $\mathbf{P}$ \\
\hline Male sex, $\mathrm{n}(\%)$ & $8(57)$ & $127(62)$ & 0.7 \\
Age, years & $60 \pm 12$ & $62 \pm 12$ & 0.3 \\
Rai stage & $0.6 \pm 1.2$ & $1.0 \pm 1.6$ & 0.4 \\
$\lg V_{H}$ mutation, \% & 71 & 59 & 0.3 \\
Beta-2 microglobulin*, mg/L & $1.7 \pm 2.0$ & $1.2 \pm 1.8$ & 0.3 \\
Flow Zap70 $\%$ \% & $7.8 \pm 12.0$ & $13.9 \pm 19.2$ & 0.5 \\
CD38 positive, $\mathrm{n}(\%)$ & $2(14.2)$ & $39(19.1)$ & 0.9 \\
CD38, \% & $7.4 \pm 11.2$ & $11.4 \pm 24.2$ & 0.5 \\
Survival from diagnosis, months & $88.0 \pm 37.2$ & $70.1 \pm 36.6$ & 0.1 \\
Deaths, $\mathrm{n}(\%)$ & $2(14)$ & $41(20)$ & 0.6 \\
\hline
\end{tabular}

Data presented as mean $\pm S D$ unless otherwise indicated. ${ }^{*}$ Normal range

$1.2 \mathrm{mg} / \mathrm{mL}$ to $2.4 \mathrm{mg} / \mathrm{mL}$; ${ }^{+}$Normal range $0 \%$ to $20 \%$

Table 3 summarizes the comparisons between the $14 \mathrm{HBV}$-positive and remaining $208 \mathrm{HBV}$-negative chronic lymphocytic leukemia patients. The sex distribution of HBV-positive cases was similar to those who tested negative ( $57 \%$ versus $62 \%$ males, respectively; $\mathrm{P}=0.70)$. Similarly, the ages of $\mathrm{HBV}$-positive versus $\mathrm{HBV}$-negative chronic lymphocytic leukemia patients were similar $(60 \pm 12$ versus $62 \pm 12$ years; $\mathrm{P}=0.30$ ). There were no differences in any of the variables associated with aggressive chronic lymphocytic leukemia including Rai stage, $\operatorname{Ig} V_{H}$ mutational status, $\beta_{2}$-microglobulin levels, Zap-70 and CD38 status, or survival times. Mortality rates were also similar in the two groups.

\section{HCV testing}

Only two of $222(0.9 \%)$ chronic lymphocytic leukemia and zero of 72 control sera tested positive for anti-HCV $(\mathrm{P}=0.42)$ (Table 4). Neither of the two anti-HCV positive chronic lymphocytic leukemia nor any of the anti-HCV-negative sera (chronic lymphocytic leukemia or controls) were HCV-RNA positive in sera. However, HCV-RNA testing was positive in peripheral blood lymphocytes of an additional two $(0.9 \%)$ chronic lymphocytic leukemia patients and one $(1.4 \%)$ control subject $(\mathrm{P}=0.72)$. Thus, a total of four $(1.8 \%)$ chronic lymphocytic leukemia patients and one (1.4\%) control subject tested positive for HCV exposure or infection (OR 1.3 [95\% CI 0.2 to 6.4]; $\mathrm{P}=0.81$ ).

Table 4 summarizes the comparisons between the four $\mathrm{HCV}$-positive and $204 \mathrm{HCV}$-negative chronic lymphocytic leukemia patients. There were no differences in sex distribution (50\% versus $62 \%$ males, respectively; $\mathrm{P}=0.58)$ or mean ages $(60 \pm 23$ versus $62 \pm 12$ years; $\mathrm{P}=0.7)$ between the two groups. As with HBV, there were also no differences in the variables associated with aggressive chronic lymphocytic leukemia or mortality rates.

\section{DISCUSSION}

The results of the present study do not support the hypothesis that HBV or HCV infection play an important role in the pathogenesis of chronic lymphocytic leukemia. Although the number of infected patients was small, the results also argue against either virus contributing to a more aggressive course of chronic lymphocytic leukemia. Finally, the results suggest that the prevalences of occult HBV and $\mathrm{HCV}$ infection are low in this particular patient population.

Although there have been numerous reports describing chronic $\mathrm{HBV}$ and $\mathrm{HCV}$ infections in patients with various hematological malignancies, there have been few studies specifically documenting the prevalences of these viruses in patients with chronic lymphocytic leukemia $(1,2,8,18,22)$. Moreover, in the limited number of studies that have been published to date, conflicting results have been reported (17-22). In the present study, we did not observe a significant
TABLE 4

Comparisons of hepatitis C virus (HCV)-positive and HCVnegative chronic lymphocytic leukemia patients

\begin{tabular}{|c|c|c|c|}
\hline & \multicolumn{2}{|c|}{ HCV } & \multirow[b]{2}{*}{$\mathbf{P}$} \\
\hline & $\begin{array}{c}\text { Positive } \\
(n=4)\end{array}$ & $\begin{array}{c}\text { Negative } \\
(n=218)\end{array}$ & \\
\hline Male sex, $\mathrm{n}(\%)$ & $2(50)$ & $127(62)$ & 0.6 \\
\hline Age, years & $60 \pm 23$ & $62 \pm 12$ & 0.7 \\
\hline Rai stage & $1.0 \pm 1.2$ & $1.0 \pm 1.6$ & 0.9 \\
\hline $\lg V_{H}$ mutation, $\%$ & 25 & 60 & 0.2 \\
\hline Beta-2 microglobulin*, mg/L & $2.7 \pm 2.4$ & $1.2 \pm 1.8$ & 0.1 \\
\hline Flow Zap70 7 , \% & $40.0 \pm 56.6$ & $13.0 \pm 17.9$ & 0.05 \\
\hline CD38 positive, $n(\%)$ & $1(25)$ & $40(18)$ & 0.7 \\
\hline CD38, \% & $40 \pm 67$ & $10.4 \pm 22.8$ & 0.1 \\
\hline Survival from diagnosis, months & $60.7 \pm 24.0$ & $71.5 \pm 37.0$ & 0.6 \\
\hline Deaths, n (\%) & $1(25)$ & $41(20)$ & 0.8 \\
\hline
\end{tabular}

Data presented as mean $\pm S D$ unless otherwise indicated. *Normal range $1.2 \mathrm{mg} / \mathrm{mL}$ to $2.4 \mathrm{mg} / \mathrm{mL}$; ${ }^{+}$Normal range $0 \%$ to $20 \%$

increase (or decrease) in the prevalence of either HBV or HCV markers relative to our healthy control population. The possible exception was a higher prevalence of anti-HBc in chronic lymphocytic leukemia patients, in whom the difference achieved a $\mathrm{P}$ value of 0.054 . It should be noted, however, that the rate of false-positive anti-HBc testing is relatively high, particularly in the setting of negative $\mathrm{HBs} A g$, antiHBs and HBV-DNA results (27). It should also be noted that our chronic lymphocytic leukemia population was older and included more males than the control population and, therefore, these demographic features would have favoured a higher overall prevalence of HBV infection (and anti-HBc positivity) in the chronic lymphocytic leukemia group (28). Whether the higher prevalence of anti-HBc could also be explained by differences in the ethnicity of patients and controls cannot be determined because ethnicity was not recorded in either group.

Regardless of whether HBV or HCV contributes to the development of chronic lymphocytic leukemia, it remains conceivable that either virus could alter the natural history or aggressiveness of the malignancy (29). Here again, we were unable to find reason for concern in that Rai staging and the distribution of established markers for chronic lymphocytic leukemia aggressiveness, such as $\lg V_{H}$ mutational status, $\beta_{2}$-microglobulin levels, Zap-70 and CD38 status, were similar in chronic lymphocytic leukemia patients with and without evidence of HBV or HCV infection (30). Further supporting this contention were the survival times and mortality rates, which were similar in infected and uninfected patients. However, the numbers of subjects with evidence of HBV or HCV infection were low and, therefore, no definitive conclusion can be drawn regarding whether either virus alters the course of chronic lymphocytic leukemia.

All of the samples tested in the present study were obtained shortly after the diagnosis of chronic lymphocytic leukemia and before institution of chemotherapy. Thus, the risk of chemotherapy converting occult HBV or HCV into clinically or serologically apparent infections in this population could not be addressed (31-33). However, the limited number of subjects with HBV-DNA or HCV-RNA in peripheral blood lymphocytes, a potential source of residual virus in occult infection, renders the likelihood of such events occurring unlikely. Nevertheless, because liver biopsies were not available for viral genomic testing, we cannot make firm recommendations regarding the need for antiviral prophylaxis (at least with respect to HBV) in anti$\mathrm{HBc}$ positive patients with chronic lymphocytic leukemia who are being considered for chemotherapy and, hence, ongoing vigilance is warranted.

There were certain limitations to the present study that warrant discussion. First, the control population was small and was not matched for age and sex; however, as mentioned previously, the 
demographics of the chronic lymphocytic leukemia and control groups would favour a higher rather than lower prevalence of HBV and HCV in the former group. Second, data regarding previous antiviral treatments for HBV or HCV were not available. However, were one to assume that some chronic lymphocytic leukemia patients were successfully treated for HBV and/or HCV infections, such treatments would not have significantly impacted the detection of virus-associated antibodies (28). Third, the patient database did not include results of testing for liver enzyme abnormalities or imaging of the hepatobiliary system. Fourth, there were numerous limitations associated with the detection assays that could have resulted in an under- or overestimation of the prevalence of occult HBV and HCV in this population (34). Finally, given that both HBV and HCV infections can exist despite negative testing of sera and peripheral blood lymphocytes, the lack of liver tissue precludes a definitive conclusion being drawn

\section{REFERENCES}

1. Molagic V, Arama V, Cercel AS, et al. Preliminary data on the involvement of $\mathrm{B}, \mathrm{C}$ and $\mathrm{D}$ hepatitis viruses in the etiopathogenesis of chronic lymphoproliferative syndromes in Romania. Rom J Intern Med 2009;47:25-34.

2. Vladareanu AM, Ciufu C, Neagu AM, et al. The impact of hepatitis viruses on chronic lymphoproliferative disorders preliminary results. J Med Life 2010;3:320-9.

3. Fazi C, Dagklis A, Cottini F, et al. Monoclonal B cell lymphocytosis in hepatitis $\mathrm{C}$ virus infected individuals. Cytometry B Clin Cytom 2010;78(Suppl 1):S61-8.

4. Becker N, Schnitzler P, Boffetta P, et al. Hepatitis B virus infection and risk of lymphoma: Results of a serological analysis within the European case-control study Epilymph. J Cancer Res Clin Oncol 2012;138:1993-2001.

5. Varma S, Menon MC, Garg A, et al. Hepatitis C virus infection among patients with non-Hodgkin's lymphoma in northern India. Hepatol Int 2011;5:688-92.

6. Ulcickas Yood M, Quesenberry CP, et al. Incidence of nonHodgkin's lymphoma among individuals with chronic hepatitis B virus infection. Hepatology 2007;46:107-12.

7. Marcucci F, Mele A, Spada E, et al. High prevalence of hepatitis B virus infection in B-cell non-Hodgkin's lymphoma. Haematologica 2006;91:554-7.

8. Bianco E, Marcucci F, Mele A, et al. Prevalence of hepatitis C virus infection in lymphoproliferative diseases other than B-cell nonHodgkin's lymphoma, and in myeloproliferative diseases: An Italian multi-center case-control study. Haematologica 2004;89:70-6.

9. Carreno V. Occult hepatitis C virus infection: A new form of hepatitis C. World J Gastroenterol 2006;12:6922-5.

10. Dal Maso L, Franceschi S. Hepatitis C virus and risk of lymphoma and other lymphoid neoplasms: A meta-analysis of epidemiologic studies. Cancer Epidemiol Biomarkers Prev 2006;15:2078-85.

11. Cougot D, Neuveut C, Buendia MA. HBV induced carcinogenesis. J Clin Virol 2005;34(Suppl 1):S75-8.

12. Zhang X, Zhang H, Ye L. Effects of hepatitis B virus X protein on the development of liver cancer. J Lab Clin Med 2006;147:58-66.

13. Lupberger J, Hildt E. Hepatitis B virus-induced oncogenesis. World J Gastroenterol 2007;13:74-81.

14. Jin DY. Molecular pathogenesis of hepatitis C virus-associated hepatocellular carcinoma. Front Biosci 2007;12:222-33.

15. Koike K. Molecular basis of hepatitis $\mathrm{C}$ virus-associated hepatocarcinogenesis: Lessons from animal model studies. Clin Gastroenterol Hepatol 2005;3(10 Suppl 2):S132-5.

16. Jahan S, Ashfaq UA, Khaliq S, Samreen B, Afzal N. Dual behavior of HCV Core gene in regulation of apoptosis is important in progression of HCC. Infect Genet Evol 2012;12:236-9.

17. Nieters A, Kallinowski B, Brennan P, et al. Hepatitis C and risk of lymphoma: Results of the European multicenter case-control study EPILYMPH. Gastroenterology 2006;131:1879-86.

18. Gharagozloo S, Khoshnoodi J, Shokri F. Hepatitis C virus infection in patients with essential mixed cryoglobulinemia, multiple myeloma and chronic lymphocytic leukemia. Pathol Oncol Res 2001;7:135-9. regarding the prevalence of occult $\mathrm{HBV}$ and $\mathrm{HCV}$ infections in chronic lymphocytic leukemia patients $(9,33,35)$.

\section{CONCLUSION}

The results of the present study do not support the hypothesis that $\mathrm{HBV}$ and HCV infections play an important role in the pathogenesis or course of chronic lymphocytic leukemia. However, larger studies including liver biopsies and age- and sex-matched controls are required to confirm these results.

ACKNOWLEDGEMENTS: The authors thank Ms Roberta Vizniak for her prompt and accurate typing of the manuscript. This research was supported by a grant from the Blood Safety Surveillance Division of the Public Health Agency of Canada.

19. Paydas S. HCV and tumors of the immune system. Leuk Res 2002;26:1141.

20. Hausfater P, Cacoub P, Sterkers Y, et al. Hepatitis C virus infection and lymphoproliferative diseases: Prospective study on 1,576 patients in France. Am J Hematol 2001;67:168-71.

21. Duberg AS, Nordstrom M, Torner A, et al. Non-Hodgkin's lymphoma and other nonhepatic malignancies in Swedish patients with hepatitis C virus infection. Hepatology 2005;41:652-9.

22. Molica S, Mirabelli R, Misuraca D. Characteristics and outcome of B-cell chronic lymphocytic leukemia in hepatitis $C$ virus-positive patients. Leuk Lymphoma 2006;47:2421-3.

23. Raimondo G, Allain JP, Brunetto MR, et al. Statements from the Taormina expert meeting on occult hepatitis $B$ virus infection. J Hepatol 2008;49:652-7.

24. Hallek M, Cheson BD, Catovsky D, et al. Guidelines for the diagnosis and treatment of chronic lymphocytic leukemia: A report from the International Workshop on Chronic Lymphocytic Leukemia updating the National Cancer Institute-Working Group 1996 guidelines. Blood 2008;111:5446-56.

25. Jelinek DF, Tschumper RC, Stolovitzky GA, et al. Identification of a global gene expression signature of B-chronic lymphocytic leukemia. Mol Cancer Res 2003;1:346-61.

26. Chen CI, Bergsagel PL, Paul H, et al. Single-agent lenalidomide in the treatment of previously untreated chronic lymphocytic leukemia. J Clin Oncol 2011;29:1175-81.

27. Lai CL, Lau JY, Yeoh EK, et al. Significance of isolated anti-HBc seropositivity by ELISA: Implications and the role of radioimmunoassay. J Med Virol 1992;36:180-3.

28. Minuk GY, Uhanova J. Chronic hepatitis B infection in Canada. Can J Infect Dis 2001;12:351-6.

29. Chumak AA, Abramenko IV, Bilous NI, et al. Persistent infections and their relationship with selected oncologic and non-tumor pathologies. J Immunotoxicol 2010;7:279-88.

30. Dal-Bo M, Bertoni F, Forconi F, et al. Intrinsic and extrinsic factors influencing the clinical course of B-cell chronic lymphocytic leukemia: Prognostic markers with pathogenetic relevance. J Transl Med 2009;7:76.

31. Yagci M, Ozkurt ZN, Yegin ZA, et al. Hepatitus B virus reactivation in HBV-DNA negative and positive patients with hematological malignancies. Hematology 2010;15:240-4.

32. Lee WM, Polson JE, Carney DS, et al. Reemergence of hepatitis C virus after 8.5 years in a patient with hypogammaglobulinemia: Evidence for an occult viral reservoir. J Infect Dis 2005;192:1088-92.

33. Rossi D, Sala L, Minisini R, et al. Occult hepatitis B virus infection of peripheral blood mononuclear cells among treatment-naïve patients with chronic lymphocytic leukemia. Leuk Lymphoma 2009;50:604-11.

34. Valentine-Thon E. Quality control in nucleic acid testing - where do we stand? J Clin Virol 2002;(25 Suppl 3):S13-21.

35. Chen MH, Hsiao LT, Chiou TJ, et al. High prevalence of occult hepatitis B virus infection in patients with B cell non-Hodgkin's lymphoma. Ann Hematol 2008;87:475-80. 


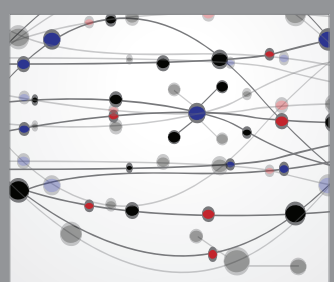

The Scientific World Journal
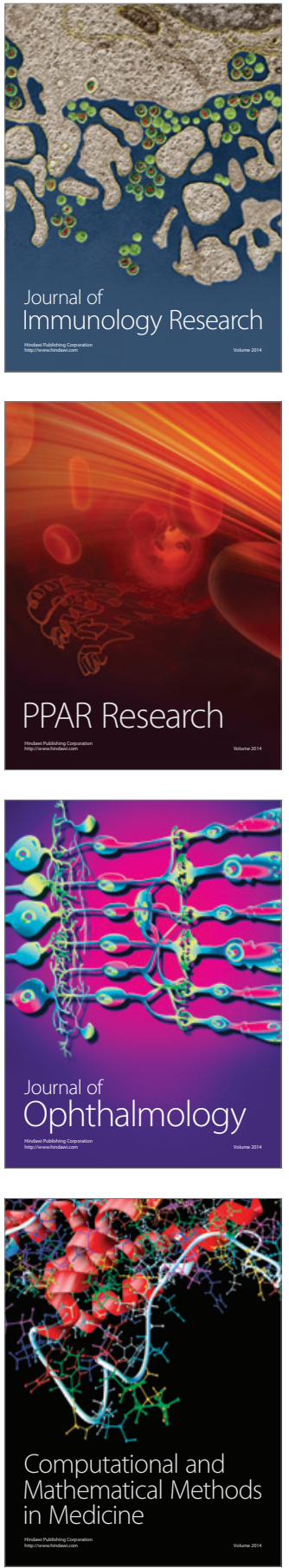

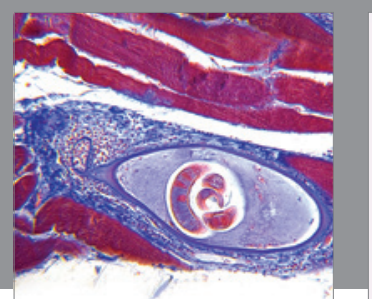

Gastroenterology Research and Practice

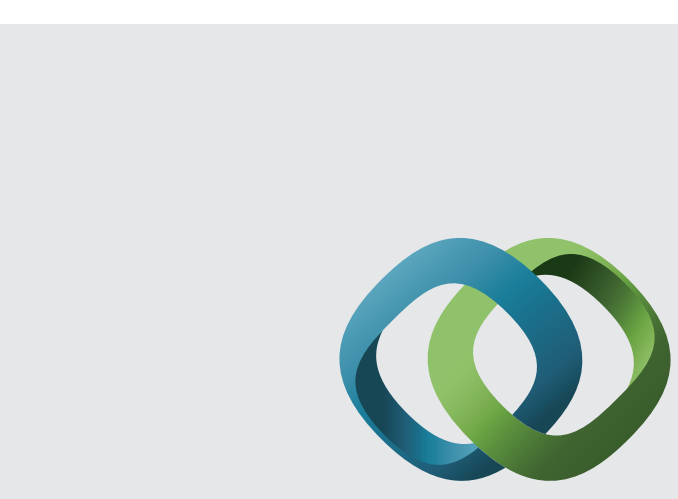

\section{Hindawi}

Submit your manuscripts at

http://www.hindawi.com
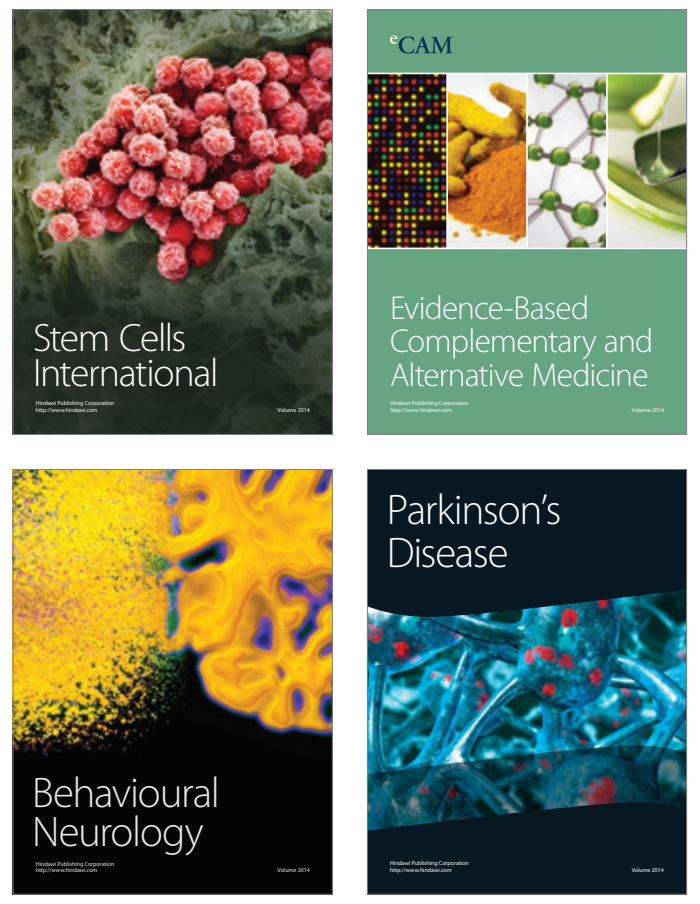
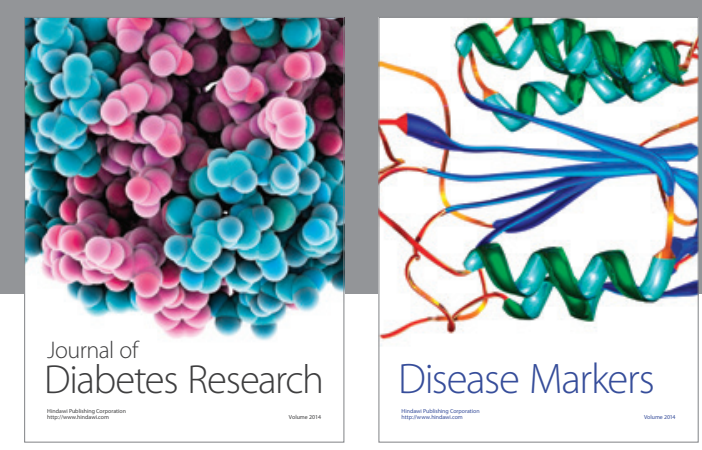

Disease Markers
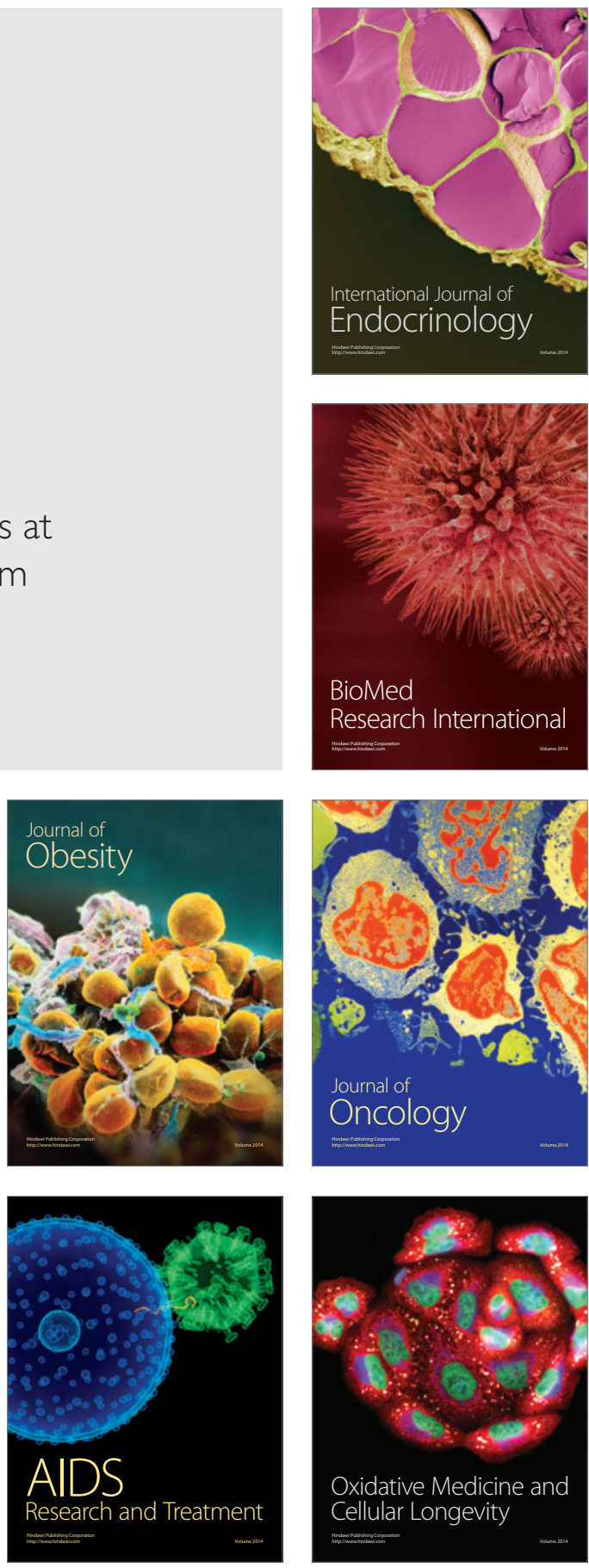